\title{
Hypothenemus hampei ferrari (coleoptera: curculionidae) answer to visual and olfative stimuli in field
}

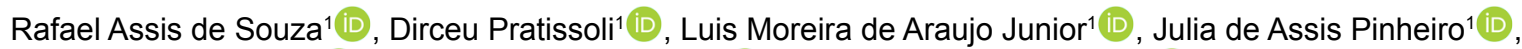 \\ Jean Francisco Vimercati Souza ${ }^{1}$ (D), Fernando Zanotti Madalon² (iD), Francieli Destefani Deolindo ${ }^{1}$ (D), Alixelhe Pacheco Damascena ${ }^{1}$ \\ ${ }^{1}$ Universidade Federal do Espirito Santo/UFES, Alegre, ES, Brasil \\ ${ }^{2}$ Universidade de São Paulo/USP, Departamento de Entomologia e Acarologia, Piracicaba, SP, Brasil \\ Contact authors: souza.rafaelassis@gmail.com, dirceu.pratissoli@gmail.com, luisjrmoreira@gmail.com, juliaassis1@hotmail.com, jeanfrancisco22@hotmail.com, \\ fernandozanottimadalon@gmail.com, francieli.destefani@yahoo.com.br, xellydamascena@hotmail.com \\ Received in October 22, 2019 and approved in May 26, 2020
}

\begin{abstract}
The coffee berry borer (CBB), Hypothenemus hampei (Ferrari, 1867) (Coleoptera: Curculionidae: Scolytinae) is one of the main pests of world coffee growing. For the purpose of monitoring the presence of this insect, colored traps and attractives have been developed. Then, the objective of this work was to determine the association between trap colors and ethanol: methanol proportions in the CBB catch, and also to determine the infestation in the coffee plantation by the $\mathrm{H}$. hampei. Painted traps of red, green and colorful (red upper half + green lower half) and six volatile mixtures were used. The reference mixtures consisted of ethanol: methanol (E:M), in the proportions of 1:1 and 1:3, with addition of 0.002 and $0.004 \mathrm{~kg}$ of pure caffeine powder. The infestation in the coffee plantation was determined by the $H$. hampei number count into the fruits and the traps. The insects caught number showed significant interaction between the factors color and mixtures of volatile compounds $\left(F_{107: 85}=2.46 ; p<0.05\right)$. The peaks of $H$. hampei infestation occurred in the stages of grain formation (January) and maturation (April). The red traps with attractive E:M 1:1 + Benzoic Acid had the most significant effects in the H. hampei catch.
\end{abstract}

Key words: Monitoring; pest; semiochemicals; volatile attractive.

\section{INTRODUCTION}

The phytophagous insects use a combination of visual and chemical stimuli to locate host plants (Bernays; Chapman, 1994). A large number of insects can visually identify the shape and color of the host (Briscoe; Chittka, 2001).

In some scolytine, the visual and olfactory stimuli have been successfully used in monitoring, as for example in Dendroctonus frontalis (Zimmermann, 1868), Ips typographus (Linnaeus, 1758) and D. valens (Leconte, 1860) (Strom; Goyer; Shea, 2001; Shou-An; Shu-Jie, 2013; Kelsey; Westlind, 2017). The beetles use a combination of pheromones of host and of aggregation to locate them (Zhang; Schlyter, 2004). These stimuli have been studied to understand how they act the insect behavior and thereby use them in the management of some pests.

The coffee berry borer (CBB), Hypothenemus hampei (Ferrari, 1867) (Coleoptera: Curculionidae: Scolytinae), is the most important coffee pest in the world, since this pest has caused quantitative and qualitative losses in the production of arabica coffee (Coffea arabica L.) and conilon (C. canephora Pierre ex A. Froehner) (Dufour; Frérot, 2008; Fernandes et al., 2015; Aristizábal et al., 2015). Only in Brazil, world's largest coffee producer, the annual losses exceed \$ 300 million (Oliveira et al., 2013; Mota et al., 2017).

Several trap models, to capture the CBB, have been developed and tested in several coffee producing countries. The developed models were: D MULTIPLE FUNNEL in France (Mathieu; Brun; Frérot, 1997) BROCAP in El Salvador and Hawaii (Dufour; Frérot, 2008; Messing, 2012), respectively; IAPAR in Brazil (Silva; Ventura; Morales, 2006; Uemura-Lima et al., 2010; Fernandes et al., 2015) and FIESTA in Colombia (Aristizábal et al., 2015).

Usually, the traps are painted in different colors and have volatiles based on attractive alcohols to the CBB (Mathieu; Brun; Frérot, 1997; Silva; Ventura; Morales, 2006; Dufour; Frérot, 2008). The transparent green traps have stood out in the attractiveness of the CBB (Silva; Ventura; Morales, 2006). Regarding the attractiveness of volatile compounds ethanol: methanol, the mixing these compounds in proportion $1: 1$ and 1:3 has been shown to be most effective at capturing CBB (Silva; Ventura; Morales, 2006; Dufour; Frérot, 2008; Mathieu; Brun; Frérot, 1997).

Laboratory and field studies have shown that CBB females use visual and olfative stimuli to locate and colonize coffee fruits (Giordanengo; Brun; Frérot, 1993; Mathieu; Brun; Frérot, 1997; Mendesil et al., 2009). Both stimuli have an important role in preference of the $\mathrm{CBB}$ for ripe fruits (reds) or immature (greens) (Giordanengo; Brun; Frérot, 1993; Mathieu; Brun; Frérot, 1997; Silva; Ventura; Morales, 2006; Dufour; Frérot, 2008). The olfative stimuli used by the CBB to locate the plant, are mainly the semiochemicals released by coffee fruits at different stages of maturation (Giordanengo; Brun; Frérot, 1993; Mathieu et al., 2001; Mendesil et al., 2009; 
Cruz; Malo, 2013). With regard to smell, generally, the red fruits are more attractive than green fruits (Giordanengo; Brun; Frérot, 1993).

Studies have been conducted with different kinds of trap colors and proportions of alcohols to attract CBB (Mathieu; Brun; Frérot, 1997; Silva; Ventura; Morales, 2006; Dufour; Frérot, 2008). However, studies that associate trap colors and attractive volatiles are few. Besides that, there are many divergences in studies of attractiveness of CBB to the colors of the traps and mix proportions methanol and ethanol (Mathieu; Brun; Frérot,1997; Silva; Ventura; Morales, 2006; Dufour; Frérot, 2008). Studies that associate visual and olfative stimuli can be fundamental in understanding the insect behavioral responses in plant location.

The color discrimination associated with olfative stimuli is essential when choosing coffee fruit by the insect (Mathieu et al., 2001). Besides that, the identification of the highest insect peak season in coffee plantation can help the farmers in decision making (Aristizábal; Lara; Arthurs, 2012; Fernandes et al., 2014; Fernandes et al., 2015). Then, the present work aimed to determine the association between trap colors and proportions ethanol: methanol, besides determining the time of greatest insect transit in coffee plantation.

\section{MATERIAL AND METHODS}

The study was carried out in a field of Coffea arabica of the variety "IAC 44" of the grow crops 'Catuaí Vermelho' with 10 years old, grown in spacing of $1.0 \times 2.0 \mathrm{~m}$, located in Celina district, municipality of Alegre $\left(20^{\circ} 45^{\prime} 50.28^{\prime \prime} \mathrm{S}\right.$ and $41^{\circ} 35^{\prime}$ 30.72" W; altitude of 700 m), Espírito Santo state, Brazil. The region climate, according to Köeppen and Geiger classification, is type "Aw", with dry season in winter; average annual temperature of $23.1{ }^{\circ} \mathrm{C}$ and annual precipitation around 1134 $\mathrm{mm}$ (Climate-Data.org, 2020). It is noteworthy that, $23 \mathrm{~mm}$ of precipitation is June, which is the driest month. December is the month with the most precipitation, presenting an average of 204 $\mathrm{mm}$. Insecticides were not applied to the crop.

\subsection{CBB capture in the traps}

The traps were made with bottles of $2 \mathrm{~L}$ of polyethylene terephthalate, with rectangular side opening $(0.2 \times 0.15 \mathrm{~m})$. They did not have costs, because they came from materials for recycling (Fernandes et al., 2015). The bottles were painted with red, green and red + green oil paint. In this last one, the upper half of the bottle was painted of red and the lower half was painted of green. The traps were attached to bamboo piles $1.5 \mathrm{~m}$ above the ground with number 12 galvanized wire (Silva; Ventura; Morales, 2006; Uemura-Lima et al., 2010). Inside each trap, one $12 \mathrm{~mL}$ clear plastic flask was contained by the chemical compounds and fixed with a string. The bottle was sealed with a plastic screw cap, with a $0.002 \mathrm{~m}$ diameter hole in the center, to release the attractive. At the bottom of the trap was added $120 \mathrm{~mL}$ of water with $5 \%$ neutral detergent to capture the CBB adults.

Six volatile mixtures were used. The reference mixtures used in all assays consisted of ethanol ( $99.9 \%$ of purity) and methanol (100\% of purity). The volume of each mixture was $12 \mathrm{~mL}$, in the proportions of $1: 1$ and $1: 3$, with addition of 0.002 and $0.004 \mathrm{~kg}$ of pure caffeine powder. The benzaldehyde (99.5\% of purity) at $0.5 \%$ (B) and the benzoic acid $(99.9 \%$ of purity) at $1 \%(\mathrm{AB})$ were added in these two proportions. The cost per trap was $\mathrm{R} \$ 1.00$ to $\mathrm{R} \$ 1.50$.

The trap opening has been positioned to the center of between the lines of the coffee, to enable the odoriferous plume of the attractive to disperse between the ranks (Fernandes et al., 2014). The experiment were conducted in randomized blocks with double factorial $(3 \times 6)$ and six blocks. The factor 1 consisted of three colors: red; green; and colorful (red + green). The factor 2 consisted of six mixtures of volatile compounds [ethanol (E): methanol $(\mathrm{M})+$ pure caffeine powder + benzaldehyde (B) + benzoic acid (BA)] in the proportions:

a) $\mathrm{E}: \mathrm{M}(1: 1)+0.002 \mathrm{~kg}$ of pure caffeine powder - E:M 1:1;

b) $\mathrm{E}: \mathrm{M}(1: 1)+0.002 \mathrm{~kg}$ of pure caffeine powder + benzaldehyde

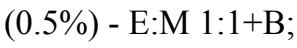

c) $\mathrm{E}: \mathrm{M}(1: 1)+0.002 \mathrm{~kg}$ of pure caffeine powder + benzoic acid (1\%) - E:M 1:1+BA;

d) E:M (1:3) + $0.004 \mathrm{~kg}$ of pure caffeine powder - E:M 1:3;

e) E:M (1:3) $+0.004 \mathrm{~kg}$ of pure caffeine powder + benzaldehyde $(0.5 \%)$ - E:M 1:3+B;

f) $\mathrm{E}: \mathrm{M}(1: 3)+0.004 \mathrm{~kg}$ of pure caffeine powder + benzoic acid (1\%) - E:M 1:3+BA.

108 traps were distributed over an area of 80,000 $\mathrm{m}^{2}$, with spacing of $15 \mathrm{~m}$ between them in a straight line. Therefore, each block was $12.75 \mathrm{~m}^{2}$ composed of 18 traps, given the combination of the three colors and six mixtures of volatile compounds. The average density was 14 traps per hectare. The experimental data were collected at harvest 2016/2017 in the following phenological stages of coffee: small green, expansion, grain formation, maturation and offseason (Camargo; Camargo, 2001).

Every 15 days, the volatile compounds were replaced and the insects were collected from the traps and taken to the laboratory to count the $\mathrm{CBB}$.

\subsection{Incidence of CBB in the field}

The incidence of CBB borer in the crop was determined in the stages of small green, expansion, grain formation and maturation. A sample of 300 fruits per plot was randomly collected. The fruits were removed in the middle third of 20 plants. The fruit evaluations were carried out at distances of 100 $\mathrm{m}$ between plants, in the direction of the coffee rows, and every $50 \mathrm{~m}$ between rows. After collection, the fruits were taken to the laboratory to count the bored fruits (Souza et al., 2013a). 
The data were subjected to analysis of variance and the means were compared by Tukey test at $5 \%$ probability in the statistical software R (ExDes.pt package) (R Development Core Team, 2019).

\section{RESULTS AND DISCUSSION}

The number of insects caught showed significant interaction between the factors color and mixtures of volatile compounds $\left(\mathrm{F}_{107: 85}=2.46 ; \mathrm{p}<0.05\right)$ (Table 1$)$.

Just in the mixture of volatile compounds E:M 1:1+ BA there was significant difference in at least one of the colors averages $(F 107: 85=2.78 ; p<0.05)$. In this case, the number of insects caught in the red traps $(616.00 \pm 41.77$ insects $)$ did not differ from the green traps (455.16 \pm 39.49 insects), but differed from the colorful traps ( $261.33 \pm 18.25$ insects $)$. However, there was no significant difference between the number of insects caught in the green and colorful traps.

The greatest attraction of the CBB by the red color was observed in results obtained from different studies (Mathieu; Brun; Frérot, 1997; Dufour; Frérot, 2008). In the results found by Silva,Ventura and Morales, (2006), the use of the transparent green trap was recommended in the monitoring of the CBB. In the present work, the attractive E:M 1:1 + BA was the only one who showed a significant difference between the traps color averages. In this case, the green color did not differ from red color and not even of the colorful, but the red color differed, with higher value, of the colorful.

The preference for red color may be related to the fact that the colors of the traps simulate the stages of fruit development, where the insect has a certain preference for ripe fruits (Giordanengo; Brun; Frérot, 1993). Besides that, the visual ability of the $\mathrm{CBB}$ is related to the fact that the color red is assimilated as black (Mathieu; Brun; Frérot, 1997). $H$. hampei colonizing females orient they self toward a dark mass and to an attractive odor source, which corresponds to visual and olfative stimuli for host recognition (Mathieu; Brun; Frérot, 1997).

The most insects have some degree of functional color vision. In beetles, this is often found as trichromatic or even tetrachromatic (based on three or four types of different photoreceptors), which allows good color discrimination for the orange / red parts of the ultraviolet spectrum (Briscoe; Chittka, 2001). The CBB females feature high visual ability due to the development of compound eyes, which makes it easy to identify colors (Vega; Infante; Johnson, 2015).

In the present study, only the red traps showed at least a significant difference between the averages of the mixtures of volatile compounds $\left(\mathrm{F}_{107: 85}=3.42 ; \mathrm{p}<0.05\right)$. In this case, the number of insects caught in the mixture of volatile compounds E:M 1:1 + BA (616.00 \pm 41.77 insects) presented significant difference, with higher value, only in relation to the mixture of volatile compounds E:M 1:3 + BA (284.00 \pm 23.05 insects) and E:M 1:3 (165.50 \pm 17.18 insects). The others mixture of volatile compounds did not differ significantly from each other.

In the perfumery industry, the benzoic acid is used in most perfumes as an artificial fixer, with the function of prolonging the effect of the aroma and slowing the essence evaporation (Castellan, 1986). Then, the significant number of CBB caught in the attractive $1: 1+\mathrm{BA}$, in the red traps, suggests that the addition of benzoic acid, at $1 \%$ in the proportion $1: 1$, prolonged the aroma effect of these alcohols by volatilization retardation. This may have enhanced the attractiveness of the mix in the red trap.

Regarding the infestation of $H$. hampei in fruits, the peaks occurred in the stages of grain formation (January) and maturation (April), both with infestation of $25 \%$ (Figure 1). In the catch in traps, the peak was in the grain formation stage (January) with 1490 insects.

Table 1: Average number of Hypothenemus hampei caught in traps with different colors and mixtures of volatile compounds in the 2016/2017 harvest, Celina district, municipality of Alegre, Espírito Santo state, Brazil.

\begin{tabular}{ccccc}
\hline & \multicolumn{3}{c}{ Color } \\
\hline Volatile compounds & Red & Green & Colorful & Average \\
\hline E:M 1:1 & $440.83 \pm 30.53 \mathrm{Aab} *$ & $246.33 \pm 20.25 \mathrm{Aa}$ & $414.33 \pm 25.33 \mathrm{Aa}$ & $367.16 \pm 25.33$ \\
E:M 1:1+B & $420.83 \pm 25.22 \mathrm{Aabc}$ & $338.50 \pm 23.25 \mathrm{Aa}$ & $420.83 \pm 26.85 \mathrm{Aa}$ & $393.38 \pm 25.10$ \\
E:M 1:1+BA & $616.00 \pm 41.77 \mathrm{Aa}$ & $455.16 \pm 39.49 \mathrm{ABa}$ & $261.33 \pm 18.25 \mathrm{Ba}$ & $444.16 \pm 33.17$ \\
E:M 1:3 & $165.50 \pm 17.18 \mathrm{Abc}$ & $212.83 \pm 17.97 \mathrm{Aa}$ & $381.83 \pm 22.25 \mathrm{Aa}$ & $253.38 \pm 19.13$ \\
E:M 1:3+B & $368.33 \pm 23.28 \mathrm{Aabc}$ & $264.50 \pm 21.20 \mathrm{Aa}$ & $258.17 \pm 18.66 \mathrm{Aa}$ & $297.00 \pm 21.04$ \\
E:M 1:3+BA & $284.00 \pm 23.05 \mathrm{Abc}$ & $244.67 \pm 16.22 \mathrm{Aa}$ & $379.33 \pm 24.77 \mathrm{Aa}$ & $302.66 \pm 21.34$ \\
Average & $382.58 \pm 26.83$ & $293.66 \pm 23.06$ & $352.63 \pm 22.68$ & \\
\hline
\end{tabular}

* Averages followed by the same capital letters in line and same lowercase letters in column do not differ from each other, at $5 \%$ probability level by Tukey test. $\mathrm{E}=$ Etanol; $\mathrm{M}=$ Metanol; $\mathrm{B}=$ Benzoaldeido; $\mathrm{BA}=$ Ácido benzoico. 


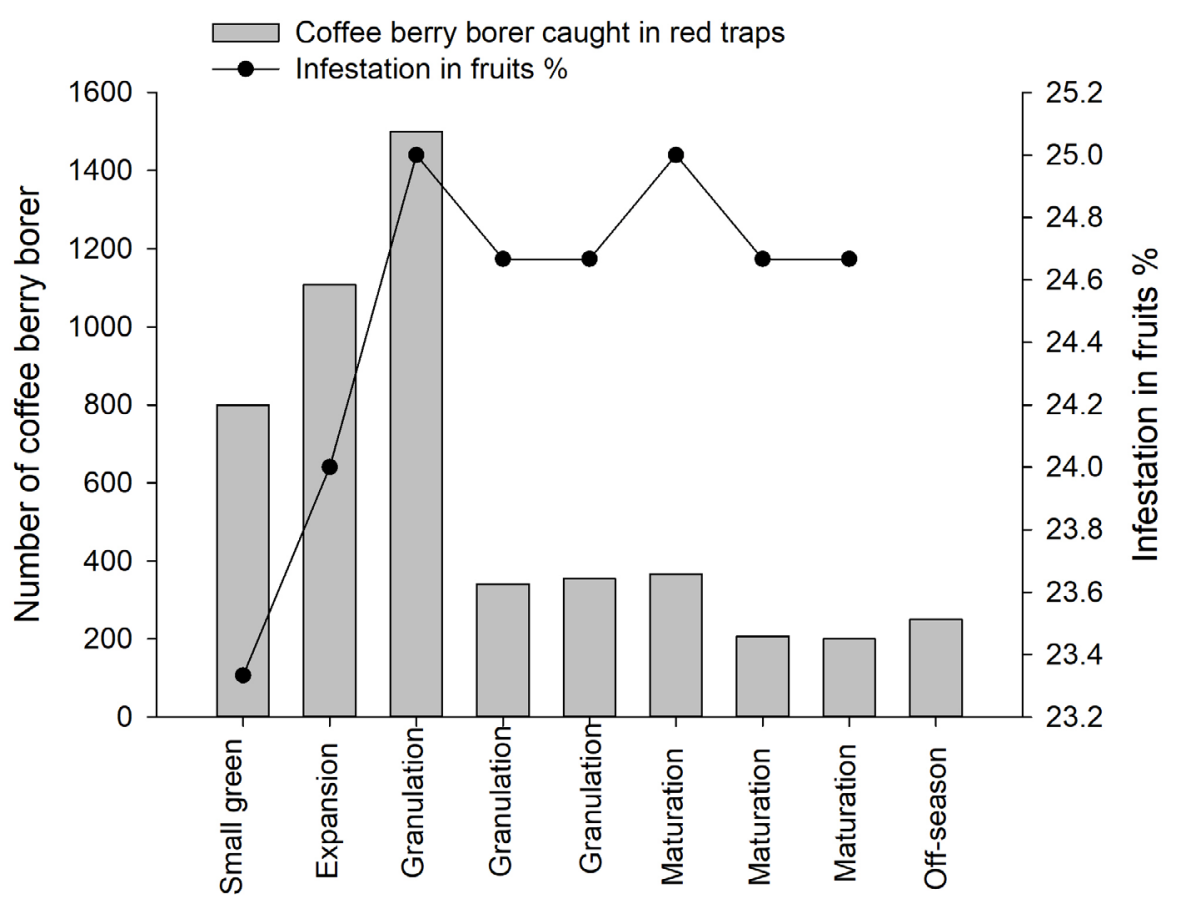

Figure 1: Number of Hypothenemus hampei adults caught in traps per month, and corresponding fruit infestation (\%) in the phenological stages of coffee (Coffea arabica), on Alegre, ES, harvest 2016/2017.

The use of red traps, containing attractive volatile alcoholic compounds reduced the percentage of boring fruits by $57 \%$ (Fernandes et al., 2014). Then, it is estimated that, only with the red traps, 75 of the 300 fruits collected per plot were not attacked during infestation peaks. However, in the present work, the possible reducing fruit infestation was not enough to keep the drill densities below the control level (CL), since the percentage of boring fruits varied from $23.3 \%$ to $25 \%$, which exceeds the value of the CL, which is $3 \%$ to $5 \%$ of boring fruits (Souza et al., 2013b).

The peak at the grain formation stage, probably, is related to insect behavior, once ninety days after the flowering, which occurs in the month of September, the CBB mated females abandon the remaining fruits of the previous harvest and fly looking for new fruits (Damon, 2000). In the small green stage, that preceding the expansion stage, the seeds, usually, have a dry matter content of less than $20 \%$. In this case, the CBB abandon the fruit after initial drilling (Jaramillo et al., 2006). After finding a fruit with at least $40 \%$ of moisture, in the expansion stage and beginning of grain formation stage, the mated female opens a hole, usually in the crown region of the fruit, and it starts the oviposition process (Damon, 2000).

The average life cycle duration of the CBB, which occurs all within the fruit, ranges from 23.3 to 53.7 days, at average temperatures of 30 and $20^{\circ} \mathrm{C}$, respectively (Jaramillo et al., 2009). After this period within the fruit, athe mated females fly in search of new fruits, which results in a new peak at the beginning of maturation stage (Fernandes et al., 2011). After the maturation stage, the CBB still has one last peak, which occurs in the off season. This shows the importance of a harvesting well done, with pass along, leaving no fruit on the plant and ground. Besides that, it is recommended to perform a pest management with traps in this period, with the purpose of decreasing the insect population density in the next harvest.

\section{CONCLUSIONS}

The mixture of volatile compounds E:M 1:1 + BA was the only one that showed significant difference between the averages of the colors of the traps in the CBB catch. In this mixture of volatile compounds, the green color did not differ from the red color neither the colorful, however the red color differed, with higher value, of the colorful.

The red color was the only one that showed significant difference between the averages of the mixture of volatile compounds in the $\mathrm{CBB}$ catch. In this color, only the mixture of volatile compounds E:M 1:1 + BA presented significant difference, with higher value, in relation to the mixture of volatile compounds E:M 1:3 + BA and E:M 1:3. It stands out, that the other mixture of volatile compounds did not differ significantly from each other.

Therefore, red traps with mixture of volatile compounds E:M 1:1 + BA had the most significant effects in the CBB catch.

The peaks of CBB infestation occurred in the stages of grain formation (January) and maturation (April), while in the traps occurred in the expansion stage (December). 


\section{ACKNOWLEDGMENTS}

This work was supported by the Coordenação de Aperfeiçoamento de Pessoal de Nivel Superior (CAPES) and Fundação de Amparo à Pesquisa e Inovação do Espírito Santo (FAPES).

\section{REFERENCES}

ARISTIZÁBAL, L. F.; LARA, O.; ARTHURS, S. P. Implementing an integrated pest man- agement program for coffee berry borer in a specialty coffee plantation in Colombia. Journal of Integrated Pest Management, 3(1):1-5, 2012.

ARISTIZÁBAL, L. F. et al. Monitoring coffee berry borer, Hypothenemus hampei (Coleoptera: Curculionidae), populations with alcohol - baited funnel traps in coffee farms in Colombia. Florida Entomologist, 98(1):381$383,2015$.

BERNAYS, E. A.; CHAPMAN, R. F. Host-plant selection by phytophagous insects. Plant Science, 102(1):117-118, 1994.

BRISCOE, A. D.; CHITTKA, L. The Evolution of Color Vision in Insects. Annual Review of Entomology, 46(1):471-510, 2001.

CAMARGO, Â. P.; DE CAMARGO, M. B. P. Definição e esquematização das fases fenológicas do cafeeiro arábica nas condições tropicais do Brasil. Bragantia, 60(1):65$68,2001$.

CASTELLAN, G. Fundamentos de Físico-Química. LTC: Rio de Janeiro. 311p. 1986.

CLIMATE-DATA.ORG. Clima Alegre. 2020. Available in: <https://pt.climate-data.org/america-do-sul/brasil/ espirito-santo/alegre-27778/>. Access in: $05 \mathrm{Abr}$. 2020 .

CRUZ, R. E. N.; MALO, E. A. Chemical analysis of coffee berry volátiles that elicit an antennal response from the coffee berry borer, Hypothenemus hampei. Journal of the Mexican Chemical Society, 57(1):321-327, 2013.

DAMON, A. A review of the biology and control of the coffee berry borer, hypothenemus hampei (Coleoptera: Scolytidae). Bulletin of Entomological Research, 90(6):453-465, 2000.

DUFOUR, B. P.; FRÉROT, B. Optimization of coffee berry borer, Hypothenemus hampei Ferrari (Col., Scolytidae), mass trapping with an attractant mixture. Journal of Applied Entomology, 132(7):591-600, 2008.
FERNANDES, F. L. et al. Economic injury level for the coffee berry borer (Coleoptera: Curculionidae: Scolytinae) using attractive traps in Brazilian coffee fields. Journal of Economic Entomology, 104(1):19091917, 2011.

FERNANDES, F. L. et al. Controle massal da broca-do-café com armadilhas de garrafa Pet vermelha em cafeeiro. Pesquisa Agropecuária Brasileira, 49(8):587-594. 2014.

FERNANDES, F. L. et al. A new and highly effective sampling plan using attractant-baited traps for the coffee berry borer (Hypothenemus hampei). Journal of Pest Science, 88(2):289-299, 2015.

FERRARI, J.A.G. Die fort und banmuzucht schadlichan borincendafer. Wien Drack und Verlag Von Carl Gerald's Sohu, 89(1):11-13, 1867.

GIORDANENGO, P.; BRUN, L. O.; FRÉROT, B. Evidence for allelochemical attraction of the coffee berry borer, Hypothenemus hampei, by coffee berries. Journal of Chemical Ecology, 19(4):763-769, 1993.

JARAMILLO, J.; BORGEMEISTER, C.; BAKER, P. Broca-do-café Hypothenemus hampei (Coleoptera: Curculionidae): Buscando estratégias de controle sustentáveis. Boletim de Pesquisa Entomológica, 96(3):223-233, 2006.

JARAMILLO, J. et al. Thermal tolerance of the coffee berry borer Hypothenemus hampei: Predications of climate change impact on a tropical insect pest. Plos One, 4(8):1$11,2009$.

KELSEY, R. G.; WESTLIND, D. J. Ethanol and primary attraction of red turpentine beetle in fire stressed ponderosa pine. Forest Ecology and Management, 396(1):44-54, 2017.

LECONTE, J. L. Synopsis of the Scaphidiidae of Estados Unidos. Transactions of the American Entomological Society, 1(1):141-178, 1860

MATHIEU, F.; BRUN, L. O.; FRÉROT, B. Factors related to native host abandonment by the coffee berry borer Hypothenemus hampei (Ferr.) (Coleoptera: Scolytidae). Journal of Applied Entomology, 121(3):175-180, 1997.

MATHIEU, F. et al. Effect of physiological status on olfactory and visual responses of female Hypothenemus hampei during host plant colonization. Physiological Entomology, 26(3):189-193, 2001.

MENDESIL, E. et al. Semiochemicals used in host location by coffee berry borer, Hypothenemus hampei. Journal of Chemical Ecology, 35(8):944-950, 2009. 
MESSING, R. H. The coffee berry borer (Hypothenemus hampei) invades Hawaii: Preliminary investigations of traps response and alternate hosts. Insects, 3(1):640-652, 2012.

MOTA, L. H. C. et al. Autoinoculation trap for management of Hypothenemus hampei (Ferrari) with Beauveria bassiana (Bals.) in coffee crops. Biological Control, 111(1):32-39, 2017.

OLIVEIRA, C. M. et al. Economic impact of exotic insect pests in Brazilian agriculture. Journal of Applied Entomology, 137(1):1-15, 2013.

R DEVELOPMENT CORE TEAM. 2019. R: A language and environment for statistical computing. R Foundation for Statistical Computing: Vienna. Available in: <https:// www.R-project.org/>. Access in: 27 Mai. 2019.

SILVA, F. C.; VENTURA, M. U.; MORALES, L. Capture of Hypothenemus hampei (Ferrari) (Coleoptera: Scolytidae) in response to trap characteristics. Scientia Agricola, 63(1):567-571, 2006.

SOUZA, J. C. de et al. Controle químico da broca-do-café com cyantraniliprole. Coffee Science, 8(4):404-410, 2013a.

SOUZA, J. C. de et al. Cafeicultor: saiba como monitorar e controlar a broca-do-café com eficiência. Belo Horizonte: Epamig, 2013b. 3p. (Epamig. Circular técnica, 178).
SHOU-AN, X.; SHU-JIE, L. V. Effect of different semiochemicals blends on spruce bark beetle, Ips typographus (Coleoptera: Scolytidae). Entomological Science, 16(1):179-190, 2013.

STROM, B. L.; GOYER, R. A.; SHEA, P. J. Visual and olfactory disruption by the wester pine beetle to attractant baited traps. Entomologia Experimentalis et Applicata, 100(1):63-67, 2001.

UEMURA-LIMA, D. H. et al. Responses of coffee berry borer, Hypothenemus hampei (Ferrari) (Coleoptera: Scolytidae) to vertical distribution of methanol: ethanol traps. Neotropical Entomology, 39(1):930-933, 2010.

VEGA, F. E.; INFANTE, F.; JOHNSON, A. J. The genus Hypothenemus, with emphasis on $H$. hampei, the coffee berry borer. In: VEGA, F. E.; HOFSTETTER, R. W. (Eds.). Bark beetles: Biology and ecology of native and invasive species. San Diego: Academic Press, 2015. p. 427-494.

ZHANG, Q. H.; SCHLYTER, F. Olfactory recognition and behavioural avoidance of angiosperm nonhost volatiles by conifer-inhabiting bark beetles. Agricultural and Forest Entomology, 6(1):1-19, 2004.

ZIMMERMANN, C. Synopsis of the Scolytidae of America north of Mexico, Notes and appendix. Transactions of the American Entomological Society, 2(1):141-178, 1868. 